China Perspectives

53 | May- June 2004

Varia

\title{
Contemporary Chinese Art Under Deng Xiaoping
}

\section{Emmanuel Lincot}

\section{OpenEdition}

Journals

Édition électronique

URL : http://journals.openedition.org/chinaperspectives/2952

DOI : 10.4000/chinaperspectives.2952

ISSN : 1996-4617

\section{Éditeur}

Centre d'étude français sur la Chine contemporaine

\section{Édition imprimée}

Date de publication : 1 mai 2004

ISSN : 2070-3449

\section{Référence électronique}

Emmanuel Lincot, «Contemporary Chinese Art Under Deng Xiaoping », China Perspectives [En ligne], 53 | May- June 2004, mis en ligne le 29 décembre 2008, consulté le 10 décembre 2020. URL : http:// journals.openedition.org/chinaperspectives/2952; DOI : https://doi.org/10.4000/chinaperspectives. 2952

Ce document a été généré automatiquement le 10 décembre 2020.

(c) All rights reserved 


\title{
Contemporary Chinese Art Under Deng Xiaoping
}

\author{
Emmanuel Lincot
}

\section{NOTE DE L'ÉDITEUR}

Translated from the French original by Michael Black

1 Studying contemporary art in China is not an exclusively aesthetic choice. In the context of an emerging market, art is as much a matter of cultural economy as of sociopolitics. Thus art is not the product of an independent condition. In its imagination, as well as in its own diversity and its transformations, it encompasses and summarises the changes of a culture which is appropriating the schemes, images and notions inherited both from an age-old tradition and from the West (a West which is sometimes in close proximity, as in the case of Muslim Central Asia or Buddhist India). Artists reinterpret the original meaning in order to arrive at a proclamation of their own difference, which is usually held up as cultural nationalism. In order to understand the evolution of contemporary Chinese art, we will examine some salient facts of artistic life in the country, which was profoundly changed by the reforms initiated by Deng Xiaoping. These changes have not stopped uniting or dividing the Chinese cultural scene in its relations with a government engaged in a constant search for legitimacy, the guarantor of order, and of an orthodoxy which has been shaken by the economic opening up of the country and by globalisation ${ }^{1}$.

2 Art in China since 1979 and the first reforms, is a space where two major aspects of Chinese history at the end of the twentieth century intersect, under the two-fold aegis of political orthodoxy and of a multifarious culture (duoyuan wenhua), which oscillates constantly between the endogenous and the exogenous, between native traditions and imported cultural practices, while calling into question the aesthetic criteria of what is called the socialist-realist period ${ }^{2}$. This enormous and tumultuous mixing, often linked to acute political crises, lies at the source of a huge iconography which exercises its 
power over successive generations, and reveals itself as the arena of intense rivalries where the most diverse temporalities clash. One cannot understand, in hindsight, either the emergence of a political and reactionary pop art (the critique of mass consumption, the ironic and playful extolling of Maoism...) or the popularity of kitsch, without taking into account the irresistible infatuation, in China, with enchantment (qiguan), the post-revolutionary sentimentality. This is, by definition, one of the most anecdotal aspects, and thus the most dated, of a period marked by a sudden acceleration of history. An art of transition, kitsch in its Chinese version, marks the beginning of a concensus established between the government and public opinion about the value of money. Thus art, which was essentially, in China, that of painting and calligraphy, has become a plural phenomenon: there is not art, but arts.

The impact of the exhibition "China/Avant-garde"

The first national and avant-gardist retrospective, China/Avant-garde (Zhongguo xiandai yishu zhan), which took place at the Peking Palace of Fine Arts in $1989^{3}$, constituted a precursory event. The artistic community, on the eve of the repression of the Tian'anmen movement, gave meaning, its own meaning, to ten years placed under the sign of a self-proclaimed avant-gardism, which the successor generation was to recognise only in order to distance itself from it more effectively, thus laying claim to a total break from it and the gap between it and the traditional world of art, and in particular that of painting. The values of painting-linked to those of the scholar and the age-old myth of state culture-on which rest the framework of debate and political choice lead to the definition of new frontiers. While information-which was scattered from the 1980s onwards-and the transformation of Chinese society do not allow the historian to envisage, for the moment, an all-encompassing analysis, covering all the events which were part of the new languages of art, it does seem possible, however, to focus on the exhibitions and the new artistic professions which created the new face of a society seeking to legitimise both its Chinese identity and its contacts with the outside world.

Peking, 1989. China/Avant-garde (Nu U-Turn).

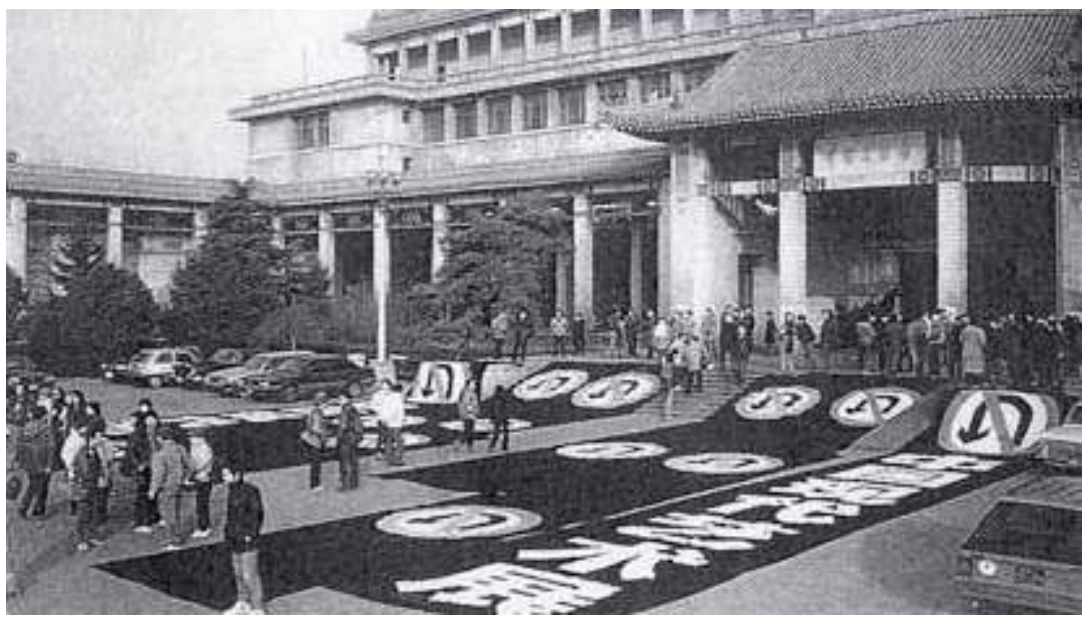

In Hung Wu, Exhibiting Experimental Art in China, op. cit., p. 16

1989 was the year of a failed revolution. It was also that of a successful aesthetic putsch, with the exhibition China/Avant-garde which opened on February 5th and brought 
together 293 paintings, sculptures and videos by 186 artists-among them Wang Guangyi, Xu Bing, Wu Shanzhuan, Huang Yongping and Gu Wenda ${ }^{4}$.

5 The event was prepared for a long time, within the framework of so-called "modern Chinese art" (Dangdai yishu yantaohui) convention, whose principles were established in November of the previous year in Tunxi in the province of Anhui. This exhibition was the result of a collaboration between three art critics: Gao Minglu, Peng De, and Li Xianting. Gao Minglu, who now teaches in the United States, was the editor at the time of the magazine Meishu. Peng De, Vice-President of the Hubei Artists' Research Institute, edited the most independent art magazine Meishu sichao, which was published in Wuhan until it was definitively censored from 1987 onwards. Li Xianting is attached to the Art Research Institute of Peking. Co-founder and editor of Zhongguo meishubao until his resignation in 1989, he remains one of the most influential critics in China.

6 China/Avant-garde did not show the public any traditional Chinese painting (guohua, literally: national painting) or calligraphy. The exhibition expertly summed up the climate of tension which, for several years, had constantly divided the art scene. China/ Avant-garde was the first national exhibition of experimental art (shiyan meishu). This is the name given to any exhibition which allows the works to produce their effect on their own, eliminating any rooting (of the work, of the criticism, of the institution) in a cult. China/Avant-garde was precisely a challenge placed in opposition to any form of cult. The event was marked by a performance by Tang Song and Xiao Lu: shots were fired at point-blank range on their installation, a telephone booth ironically entitled " duihua" (Dialogue). The organisers aimed, at those who were willing to see, tangible signs of the break between the moment of the exhibition and the public, using streamers stamped with the label "No U-Turn".

7 This mode of artistic expression was to become predominant during the following decade. The exhibition of experimental art goes against the repressive state (an expression equivalent to a pleonasm in the case of China, which has never been a liberal state). The clash between these two entities which are opposed in every way (an abstract organisation versus a concrete manifestation) could only be head-on. China/ Avant-garde was censored. The event preceded the repression of the Tian'anmen Square demonstrators, which took place three months later.

If we consider that an art as overwhelmingly cult-bound as painting-and its corollary, the veneration of an image which corresponds as much to that of the scholar as to the culture of which he is the guardian-was suddenly made available to all, one can understand that, in parallel with museum exhibition, the Chinese visual arts went into crisis (weiji). This crisis in art-and in particular in painting and calligraphy, which are considered, in China, to be at the summit of the hierarchy of aesthetic and social values ${ }^{5}$-consisted in fact in the invention of it. Where before there had been no art in the strict meaning of the word, but an object of or for worship, from then on there was art, because a question had been asked about the gesture that founds it. Each exhibition of contemporary art reinvents art by asking again the question of art, of its boundaries, and, a novelty in China, of memorisation, or of what Francis A. Yates, in a completely different context, called the art of memory, emphasising the value and the anamnestic role of history ${ }^{6}$. It took the transformation of an ancient religious art into an exhibition art, before the question of what was religious in it-its aura-could at last be asked.

Towards the disappearance of the old frameworks 
The exhibition, as place, as work, and as event, has since become a space for the transformation of the traditional categories in the domain of the visual arts. As happened in the United States and in Europe almost forty years ago, the frame, both literally and figuratively, is being shattered before our eyes, shaking up the elements of a visual language which, in the past, had assigned to the visual arts (calligraphy and painting) and to their supports (the guohua scroll, the stretcher for oil on canvas) their specificities in terms of domain: materials, hanging, places of exhibition, modalities of diffusion borrowed from Western practices. It is the work which, as is the artists' wish, leads very directly to the questioning of its exhibition, and more generally questions the role of exhibition.

In the wake of these upheavals and the profusion of experimentation, a growing number of artists abandoned the base, the frame and the scroll; the wall, the table (the conventional support for the Reading-nian-of a calligraphy or of a shanshui) were no longer pre-eminent for the presentation of works, and many of them now occupied the floor or the ceiling. The archetype of the museum, an inheritance from nineteenth century Europe and before that from the early curiosity rooms of the Renaissance, with its cultural and political implications, as well as in its very architectural configuration, was disputed; artists like Zhang Dali or Rong Rong turned to the ruins of the workers' housing estates, the disused industrial sites, an urban space which had been disrupted and which itself simultaneously disrupted the choice of exhibition venues.

Rong Rong, photograph, untitled.

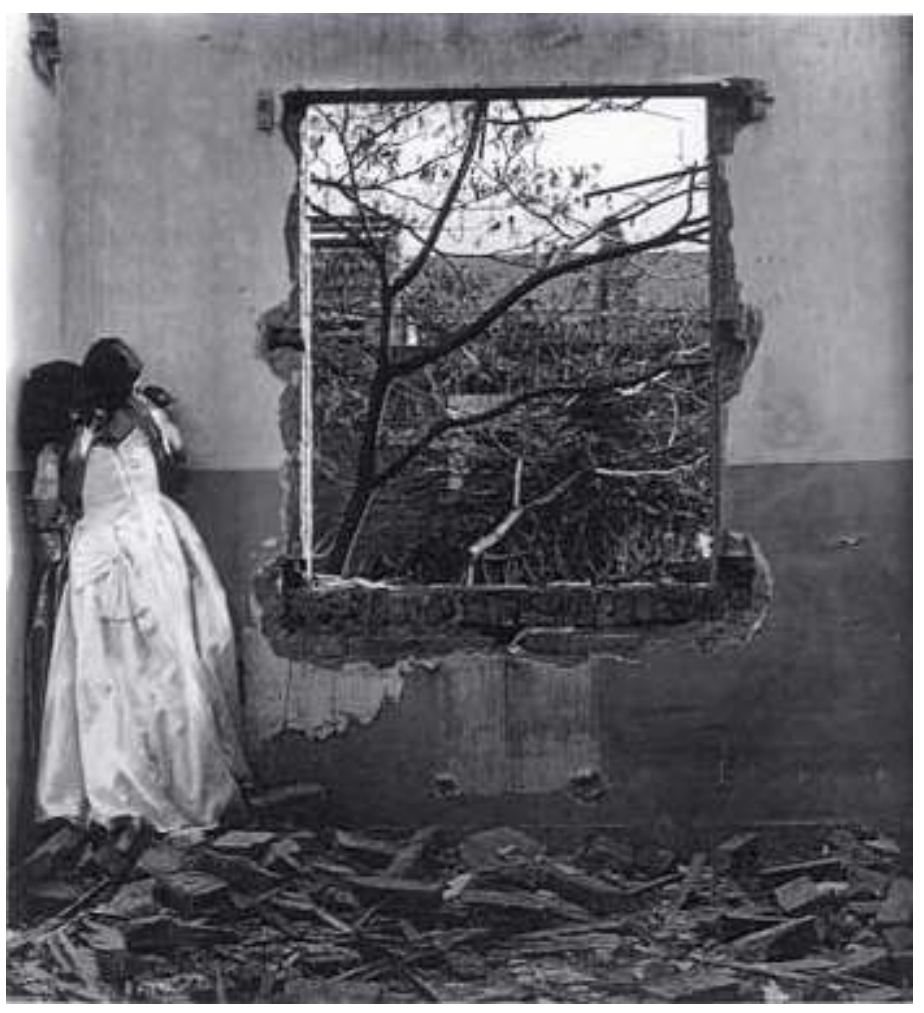

In Emmanuel Lincot, L'Invitation à la Chine, op. cit.

11 The exhibitions of experimental art in the People's Republic were discovered by art professionals from the West, Taiwan or Hong Kong at the beginning of the 1990s. The success of the international exhibition China's New Art, post-1989, organised by the Hong 
Kong gallery Hanart $\mathrm{TZ}{ }^{7}$, and the considerable attention attracted by the first participation of young Chinese artists in the 1993 Venice Biennale, as well as the publication of articles in Flash Art and The New York Times Magazine, explain the growing interest of the foreign media in the Chinese art scene, as well as the enormous prestige which artists acquired by becoming, sometimes against their will, the flag-bearers of their country.

12 Exhibition venues diversified. They tended to oppose the persistent collusion between state interests and the members of the juries, which is rarely propitious to the development of original creation. After 1989, exhibitions retreated from the art galleries and the commercial spaces, sometimes to spaces in private houses or in diplomatic compounds. Beginning in 1993, the galleries affiliated to institutions, such as those of the Teacher Training College or the Central Fine Arts Academy, became major sites of experimental exhibition in Peking, mainly because of the openmindedness shown by the directors of these establishments. These were not, however, isolated examples. Thus, Guo Shirui, director of the very official Contemporary Art Centre in Peking, began, in 1994, to organise a series of highly important artistic events. With time it became clear that these galleries and the art world in general were subject to the play of competition and to a strategy of modulable discourse which sought to transcend the constraints of government censorship and to seek public and private subsidy. This competition was at the source of the development of a contemporary art market which began with the first Canton Biennale (in October 1992). Then came Shanghai (1996), the stakes of which, on the world art scene, were upped by the French art critic Pierre Restany when he presided over the event four years later.

13 At the heart of this decision-making process was the author, at one and the same time set designer, director, interpreter and creator of the exhibition, which was conceived as a work of art where the artist, the organiser and the public met; the events became a performance. The word recalls the variety of meanings, the differentiation and the multiple temporalisation of social phenomena. The performance and its objects refer us as much to the subject as to the venue, which is to be considered as a site where the work is made, is consulted, is even booed at, and never ceases to build and rebuild itself. The fact that the work and the exhibition were constantly evolving gave the organisers a variety of ways to circumvent the constraints of censorship, for example by transferring their exhibition from China to one or several foreign countries. It was in the microworld of the experimental exhibition that were developed the newest ideas and the most powerful images, which were less and less often those of painting. The government's reluctance to facilitate these artistic events was all the more understandable in that they perturbed political arrangements and age-old cultural codes. Censorship or self-censorship leading to the cancellation of an event, constituted the symptomatic realities of a culture held in an ideological yoke which continued to exercise a fearsome constraint in the era of Deng Xiaoping.

However the real revolution in Chinese contemporary art was to be found in its integration into the logic of the market, which the national economy as a whole was then tending to embrace. This evolution was accompanied by the emergence of new socio-political categories, centred on the individual and situated on the frontier between the professions of information, of art and of politics. 


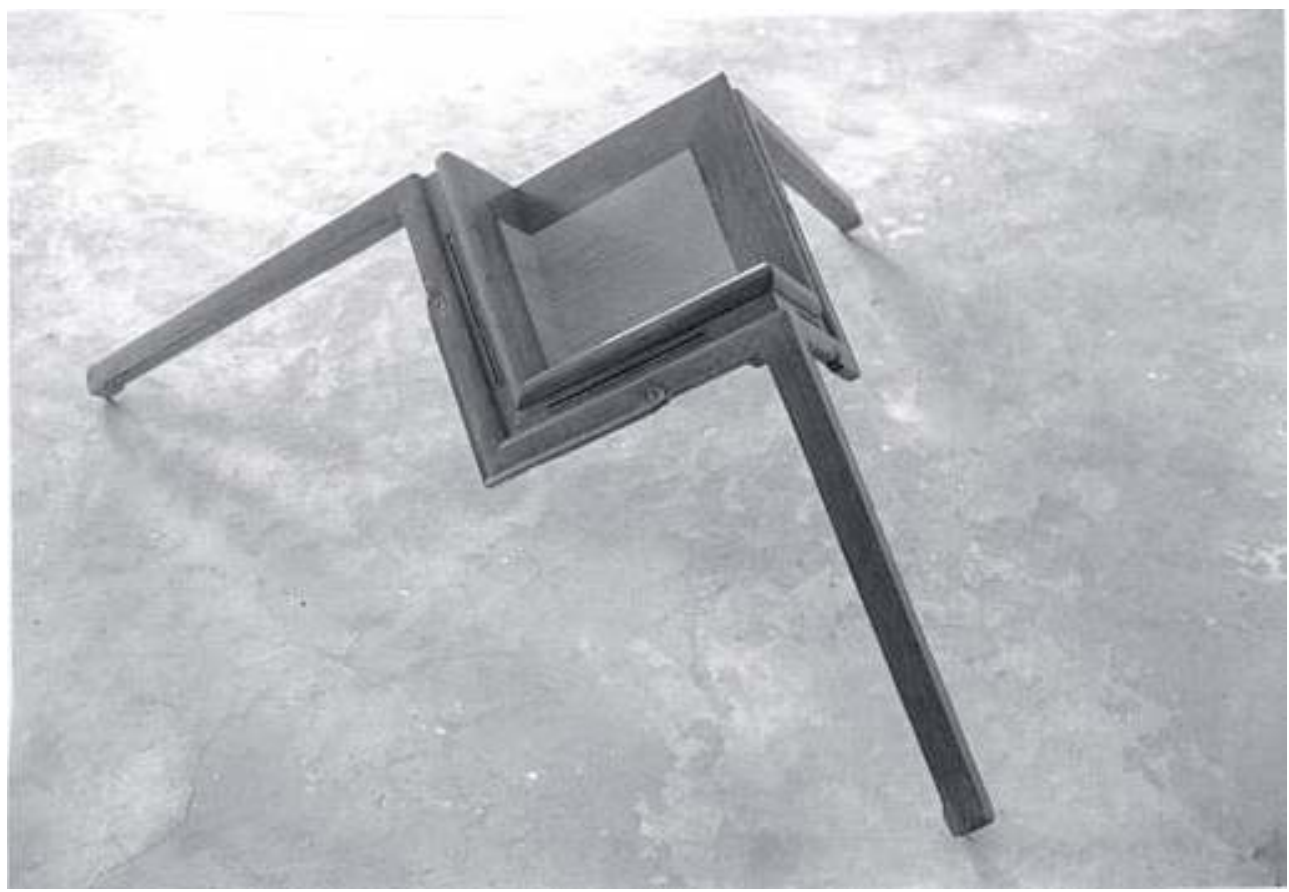

In Emmanuel Lincot, Avant-gardes (Xianfeng yishu), op. cit.

An archetype of the communicating artist : Ai Weiwei

A new profession appeared: that of critic-dealer or cultural mediator (in English "independent curator"; in Chinese "duli cezhanren"). The cultural mediator is a freelance professional who combines several functions. He is the obligatory intermediary between the Ministry of Culture, its éminences grises, the exhibition commissioner, the artists, the public, and the potential consumers. He "manufactures" opinion, describes current trends, travels, and negotiates between the parties concerned, in particular with the collector who, by means of his financial assets and social position-he is often a diplomat or an industrialist-spreads rumours, destroys reputations, drapes himself in the prestigious role of patron, of defender-on occasion -of human rights, of freedom of expression in a country where, it is true, society does not much appreciate independence or the right to be different.

The major factor in this evolution of the art scene was the appearance of selective events, in the form of performances or of exhibitions in private spaces, which tended to vary their participants and their venues without it being necessary to obtain, in a systematic way, the permission of the authorities. As this trend developed, not without coming up against real reservations (sometimes on the part of the artists themselves who preferred, for career strategies, the exclusive recognition of official circles), the field of artistic experimentation broke up into very diverse groups (in the 1980s) and then into individuals (after 1989) on the edges of the system, which increased their dependence on critics, dealers, and on a range of opinion, which was no longer restricted to the conurbations of Peking and Shanghai. Willingly or not, they were integrated into a micro-society where imagination met the internationalist economy. Virtual processes like the Internet, and other communication media, sometimes had the effect of shifting the attention of the critics and of the public onto the identitarian and even the nationalistic specificity of both the work and its producer. 
There were many examples of brilliant artistic careers. These successes were undoubtedly linked to the utilisation of the new communication media, which the artists of the new generation ingeniously turned to their advantage. The most remarkable archetype of this new kind of artist was the Pekingese Ai Weiwei. Artist, dealer, gallery owner, collector, publisher, he embodied to an extent previously unequalled, the most diverse functions which correspond to the key axioms of art communication, then still in its infancy. His way of working and his libertarian attitude made him an artist of a new kind, on the frontiers between the art world, assumed poetic dissidence, commercial opportunism, and scholarly aristocracy. As the son of the poet Ai Qing, a supporter of the regime, his pedigree opened the doors to a broad social recognition. He chose to attend the Film Institute which reopened in 1979, having been closed because of the Cultural Revolution. But neither the cinema nor China could hold the young Ai Weiwei, and after joining the Xing Xing group, he opted for expatriation in New York. There, he attended the Parsons School of Design, traded in antiques for a living, and frequented both the museums and the underground, as well as one of his mentors, William Burroughs. His reference in art was and has remained Marcel Duchamp: a choice which is symptomatic of a generation which finds its marks not in a formalist debate, but rather in the distinction between the sphere of art and of aesthetics.

In relation to this model, the journey of a work to its presumed consumer is no longer linear but forms a loop; in this it resembles a practice which existed in scholarly circles in the China of the old school. The scholar, as both man of action and man of letters, was a cultural mediator as well as an essential conveyor of the production and transmission of knowledge. For Ai Weiwei's generation, however, which stands halfway between a claim to modernity and the disenchanted ideal of the scholar-peasant which Mao Zedong embodied in the iconoclastic and revolutionary mode, the path to follow is that of consumerism and, springing from this, of the inauthenticity of works of art and their reducibility to the level of language (whether that of advertising, of the classical, of the universal or the cryptic) becoming the driving force of a reality which needs to be reinterpreted. The artist broke new ground when he suggested to the collectors and dealers Hans Van Dick and Frank Uytterhaegen that they set up a foundation in Peking, The China Modern Art Foundation, of which he is now co-director. This venue exhibits his own works (paintings, installations and sculptures), and functions as a venture in social advancement, in keeping with the nature and ambition of artistic marketing on an international scale between Peking and New York.

The integration of Chinese art in the international market

19 The novelty in China was not the marketing of works of art-which is doubtless as old as the invention of collecting-but rather their integration in the international art market. The craze for contemporary Chinese art was in keeping with a media movement with strong exotic inclinations which first began in eastern Europe, before and especially just after the fall of the Berlin Wall, and which continues to this day. At first it was private initiatives, on the part of art lovers such as the Swiss ambassador Uli Sigg, which attracted the attention of the media. Then various governments organised, with some difficulty, major retrospectives in Europe, in Australia, in the United States and in Japan. There were few galleries in China until the early 1990s-except for those established in Hong Kong. The reason for this was the endless harassment and administrative threats faced by the owners of these spaces (which were moreover much 
coveted by artists), most of whom were of foreign origin. These galleries, mostly situated in Peking and Shanghai, nevertheless had a considerable impact, for they set the prices of works of art for those who aspired to an international career 8 .

The critics often reported a perversion of the art school system and the increasing unease of the public, who assessed the works only in terms of the market speculation to which they were then subjected. This unease encouraged the authorities to adapt the art school system to the norms created by the market. Structural reforms as well as the overhaul of the training courses for students (including work experience in advertising agencies or abroad) opened up the art schools to new possibilities. The overhauling of the art schools in China (the merging of several academies, the creation of galleries with joint public and private funds), which came into effect only after the death of Deng Xiaoping, called fundamentally into question one of the canonical principles, once defined at Yan'an: art only in the service of the people.

The deep unease felt by a large number of artists and intellectuals in China in the face of this upheaval, is better explained by the fact that the last twenty years produced an extraordinary confusion in people's work and in their minds; the egalitarian and communist philosophies were succeeded by nationalistic and even xenophobic ideas of resistance to "spiritual pollution". And yet Deng Xiaoping's China was no longer, if indeed it had ever been, a cultural loner. It followed and accompanied globalisation, and, at the same time, offered resistance by the reinterpretation of a living tradition which was its own, while fundamentally calling into question the structures of the art world inherited from the Maoist period.

\section{NOTES}

1. This article is based on Emmanuel Lincot Culture, identité et réformes politiques : la peinture en République populaire de Chine (1979-1997), doctoral thesis in process of publication, University of Paris VII, 2003.

2. Cf. Julia F. Andrews, Painters and Politics in the People's Republic of China (1949-1979), Berkeley, University of California Press, 1994, and Ellen Jonston Laing, The Winking Owl: Art in the People's Republic of China, Berkeley, Los Angeles, University of California Press, 1988.

3. Hung Wu, Exhibiting Experimental Art in China, Smart Museum of Art, University of Chicago, 2000.

4. On these artists, and the period concerned, a number of journals and books in Chinese are available. We should mention in particular the book by Lu Peng and Yi Dan, Zhongguo xiandai yishu shi (1979-1989) (A History of Contemporary Chinese Art [1979-1989]), Changsha, Hunan meishu chubanshe, 1992. A journal offers a trilingual presentation (in French, Chinese and English) of these artists: Emmanuel Lincot, Avantgardes (Xianfeng yishu), published with the assistance of the French Ministry of Foreign Affairs, Peking, 1997. 
5. Cf. Kraus Richard Curt, Brushes with Power: Modern Politics and the Chinese Art of Calligraphy, Berkeley, University of California, 1991; James Cahill, The Painter's Practice. How Artists Lived and Worked in Traditional China, New York, Columbia University, 1994. 6. Francis A. Yates, L'Art de la mémoire, Paris, Gallimard, 1975.

7. China's New Art, Post-1989, organised by the Hong Kong gallery Hanart TZ, 1993.

8. A number of exhibition catalogues have been published in the West which make it possible to become more familiar with the work of some artists. In particular: Emmanuel Lincot, L'Invitation à la Chine (Biennale d'Issy-les-Moulineaux), Paris, BeauxArts, 1999 (one of the very first retrospectives of contemporary Chinese art in France); Marie-José Mondzain, Transparence, opacité ? 14 artistes contemporains chinois, Paris, Cercle d'art, 1999 (a remarkable reflection by a philosopher who specialises in the image); Jean-Marc Decrop and Christine Buci-Glucksmann, Modernités chinoises, Paris, Skira, 2003 (the collection of a Paris gallery owner with a commentary by an academic); Made by Chinese, Paris, Galerie Enrico Navarra, 2001 (a practical inventory and biographies of major contemporary Chinese institutional artists); Paris / Pékin, Espace Cardin Asiart archive, Paris, 2002 (a superb inventory of the private collection of Baron Ullens). 